\title{
КОГНІТИВНИЙ ДИСОНАНС ЯК ПСИХОЛОГО-ПЕДАГОГІЧНА ПРОБЛЕМА
}

T. I. Горпініч

\author{
ДВНЗ “Тернопільський держсавний медичний університет імені І. Я. Горбачевського МОЗ Украӥни”
}

\section{COGNITIVE DISSONANCE AS PSYCHO-PEDAGOGICAL PROBLEM}

\author{
T. I. Horpinich \\ SHEI "Ternopil State Medical University by I. Ya. Horbachevsky of MPH of Ukraine”
}

\begin{abstract}
У статті здійснено огляд останніх наукових досліджень явища когнітивного дисонансу, подано його визначення, проаналізовано роль в успішності навчальної діяльності. Когнітивний дисонанс розглянуто крізь призму педагогічного знання як стан психічного дискомфорту, який виникає у випадку неузгодженості знань, емоцій, думок у процесі пізнавальної діяльності. Окреслено перспективні напрямки у дослідженні даної проблеми.

The article presents an overview of recent investigations of the phenomenon of cognitive dissonance, gives its definition, and analyzes its role in the successful learning activity. In the light of pedagogical knowledge cognitive dissonance is viewed as a state of mental discomfort that occurs in case of the presence of two contradictory ideas, emotions, thoughts during cognitive activity. Perspective areas of research are outlined.
\end{abstract}

Вступ. Одним з найважливіших засобів підвищення успішності навчальної діяльності студента $\epsilon$ його позитивні емоційні переживання. Ситуації неуспіху служать істотною причиною зниження мотивації до навчання, формування негативних рис характеру і навіть деформації особистості. Дослідження неуспішності студентів у навчальній діяльності демонструють різні точки зору на її природу і шляхи подолання. Однак неузгодженість стилю розуміння з технологією навчання студентів як одна з причин виникнення психологічного дискомфорту у процесі навчальної діяльності, а отже,зниження успішності не піддавалася глибокому аналізу.

Традиційні технології навчання у вищій школі базуються в основному на вербалізмі, фронтальному викладі навчального матеріалу в лекційній формі, формалізмі. Наукові технології творення наочного образу, як правило, також відсутні. Відтак, у більш сприятливому становищі опиняються студенти 3 добре розвиненим аналітичним мисленням. Зорієнтованість на логіку,упорядкованість ірегламентованість методіві іприйомів навчання мимовільно ставить у незручне становище студентів з домінуванням образного мислення.

Загальноприйнятим $€$ положення про те, що урахування індивідуальних особливостей пізнавальної діяльності студентів виступає ефективним засобом в індивідуалізації навчання. Як було зазначено, у вищій школі ці особливості практично не беруться до уваги. Тим часом ігнорування відмінностей у сприйнятті, відборі, переробці й запам'ятовуванні інформації під

(C) T. I. Горпініч час навчання може призвести до тривалого внутрішньоособистісного конфлікту, а потім - до виникнення явища когнітивного дисонансу.

Вперше явище когнітивного дисонансу досліджено американським психологом Л. Фестингером. Вчений визначив когнітивний дисонанс як стан психічного дискомфорту людини, викликаний зіткненням у її свідомості протилежних знань, уявлень, цінностей або емоційних реакцій [1]. На сьогодні у психолого-педагогічній літературі $є$ велика кількість робіт, що стосуються причин виникнення когнітивного дисонансу та його наслідків для розвитку особистості.

В основу теорії когнітивного дисонансу лягли положення теорії поля К. Левіна та ідеїФ. Хайдера про так звану когнітивну рівновагу. На думку дослідника, відношення між предметами або індивідами є урівноваженими когнітивними утвореннями [2]. Положення про те, що когнітивні структури прагнуть до стійкості, рівноваги, характерне для берлінської психологічної школи (М. Вертхаймер [3], В. Келлер [4], К. Левін [5], Ф. Хайдер [6]). Теорія когнітивного дисонансу Л. Фестингера, по суті, $є$ різновидом теорії когнітивної рівноваги. На його думку, дисонанс може виникнути тоді, коли два уявлення про що-небудь не можуть бути взаємоузгоджені. Усунення дисонансу, що виник внаслідок неможливості цього узгодження, відбувається шляхом зміни поведінки, перегляду одного з уявлень, яке прийшло в суперечність, через пошук нової інформації, а можливо і через зміну переконань. Значення теорій рівноваги та дисонансу полягає в обгрунтуванні ролі когнітивних репрезентаційу навчальній діяльності. 
Основна частина. Когнітивний дисонанс, що виникає в результаті неузгодженості різних когнітивних структур, як причина зниження успішності студентів у навчальній діяльності досі не виступав як самостійний об'єкт наукового аналізу. Відповідно, метою статті є дослідження явища когнітивного дисонансу крізь призму психолого-педагогічної науки.

Основним постулатом теорії когнітивного дисонансу $€$ прагнення до гармонії зовнішнього впливу і власних поглядів та установок. Дисонанс розвивається як щось неприємне, внаслідок чого виникає прагнення знизити його і відновити узгодженість. Встановлено, що разом зі спробами усунути дисонанс суб' єкт уникає ситуацій та інформації, які могли б його збільшувати.

Стан розробки теорії когнітивного дисонансу відображено в постулатах, сформульованих Р. Зайонцом: 1) когнітивний дисонанс $є$ негативним станом; 2) у випадку когнітивного дисонансу людина намагається знизити або усунути його, діючи так, щоб уникнути подій, що підсилюють цей стан; 3 ) за наявності узгодження протилежних ідей, уявлень суб' єкт прагне уникати подій, які породжують цей дисонанс; 4) глибина або інтенсивність когнітивного дисонансу залежить від значущості відповідних знань і відносної кількості знань, що суперечать один одному; 5) сила тенденцій, зазначених у пунктах 2 i 3, прямо залежить від глибини дисонансу; когнітивний дисонанс можна знизити або усунути, тільки додавши нові знання або змінивши існуючі; 6) додавання нових знань редукує дисонанс, якщо вони посилюють одну із сторін і тим самим зменшують частку дисонансних когнітивних елементів або нові знання змінюють значущість когнітивних елементів, що суперечать один одному; 7) зміна існуючих знань знижує дисонанс, якщо новий зміст робить їх менш суперечливими щодо інших знань або їх значущість знижується; якщо нові знання не можуть бути використані або існуючі - змінені за допомогою пасивних процесів, виникає поведінка, когнітивні наслідки якої сприятимуть відновленню узгодженості [7]. Прикладом такої поведінки є пошук нової інформації.

У своій теорії Л. Фестингер визначив п’ять основних ситуацій, у яких зниження когнітивного дисонансу відіграє важливу роль в життєдіяльності суб' єкта. У контексті навчальної діяльності ці ситуації такі: 1) внутрішній конфлікт після прийняття рішення чи розв'язання навчального завдання; 2) вимушені дії у стресовій ситуації, на які сам студент не пішов би; 3) репрезентація знань і відбір інформації; 4) незгода з переконаннями соціальної групи; 5) несподівані результати дій та їх наслідків [1].

У навчальній діяльності суб'єкт найчастіше стикається із ситуацією репрезентації знань та відбору інформації. При вивченні останньої ситуації Л. Фестингер звернув увагу на специфічну особливість, яка полягає в прагненні знизити когнітивний дисонанс: люди надають перевагу тій інформації, яка підвищує цінність обраної ними раніше альтернативи поведінки. Протилежна інформація при цьому ігнорується. Однак дослідник відзначає, що ситуація репрезентації знань та відбору інформації-процес складніший, ніж просто сприйняття і селекція інформації. Навіть якщо суб'єкт звертає увагу на яку-небудь інформацію, якість ї̈ сприйняття може бути різною.

Таким чином, суть когнітивного дисонансу, розглянутого в зарубіжних теоріях когнітивної рівноваги і когнітивного дисонансу, визначається фактом виникнення суперечності між двома або кількома когнітивними елементами, які призводять до дискомфортного співвідношення між змістом когнітивних елементів і мотиваційними ефектами, що породжується прагненням до узгодженості і комфорту. Водночас стан психічного дискомфорту під час репрезентації знань та відбору інформації може бути зумовлений неузгодженістю різних когнітивних структур. 3 цієї точки зору важливою є форма пред’явлення інформації. Відповідно, одним із варіантів когнітивного дисонансу, що раніше не розглядався дослідниками, може виступати дисонанс між формою представлення інформації і тим стилем ії сприйняття і переробки, якому надає перевагу суб’єкт.

Специфіка навчальної діяльності щодня ставить людину в ситуацію репрезентації знань, і якщо процес розуміння дитиною предметно-смислового навчального матеріалу утруднений, то виникає когнітивний дисонанс, який може істотно ускладнювати процес навчання і виступати негативним фактором, що впливає на успішність навчальної діяльності та розвиток особистості студента в цілому.

Дослідження останніх років у вітчизняній та зарубіжній психології пов'язані з підвищеним інтересом до проблеми негативних наслідків, що виникають внаслідок неузгодженості технології пред’явлення інформації і стратегіï ії переробки, якій надає перевагу суб'єкт [8-10]. Особливо гостро ця проблема поставлена в межах напрямку, що отримав назву нейролінгвістичне програмування (Р. Бендлер, Дж. Гріндер, Дж. Хейлі, М. Еріксон та ін.). Психологи, які працюють у цьому напрямку, найбільшу проблему сучасної системи навчання бачать в "окультуренні учня переважно до лівопівкульних навичок” у навчальній діяльності [11]. Можна погодитися із засновниками цього напряму, що багато студентів відчувають серйозні труднощі в навчанні тільки через розбіжність між модальностями внутрішнього до- 
свіду викладача і учня - зорової, слухової або чутливої (візуальна, аудіальна, кінестетична модальності або репрезентативні системи). Коли суб'єкт звертається до свого внутрішнього досвіду, він вважає за краще робити це в одній з модальностей. Якому саме різновиду внутрішнього досвіду надає перевагу суб' єкт, можна визначити за певними зовнішніми ознаками: рухами його очей, словами-предикатами, жестами. Окрім цього, в процесі навчальної діяльності від студентів часто вимагають швидкого переходу з однієї модальності в іншу. Наприклад, початок виконання завдання вимагає залучення візуальної модальності: "Подивися на малюнок (схему)", а досягнення його кінцевої мети - аудіальної: “Дай відповідь на запитання”. Низкою авторів відзначається, що найефективнішим способом допомоги неуспішним студентам $\epsilon$ уважне ставлення до їх репрезентативних систем, ліквідація конфлікту стилів у процесі навчання [10]. У багатьох наукових розвідках автори вказують на те, що психологічний дискомфорт, зумовлений неузгодженістю технології навчання і стилем отримання та переробки інформації, може призводити до агресивності особистості стосовно учасників і самого процесу навчання, байдужого або негативного ставлення до навчальної діяльності, яке у свою чергу призводить до неуспішності в навчанні.

Потреби людини знаходять своє максимальне втілення, коли вона має можливість задовольнити їх у формах активності, максимально відповідних стилям іії індивідуальності: стилю міжособистісних взає-

\section{Списоклітератури}

1. Festinger L. Theory of Cognitive Dissonance/ L. Festinger. - Stanford: Stanford University Press, 1957. -291 p.

2. Heider F. The psychology of interpersonal relations / F. Heider. - New York : Wiley, 1958. - 322 p.

3. Wertheimer M. Experimentelle Studien uber das Sehen von Bewegung/ M. Wertheimer// Zeitschrift fur Psychologie. -1912. - Band 61. -S. 161-265.

4. Kohler W. Die physischen Gestalten in Ruhe und im stationaren Zustand : eine naturphilosophische Untersuchung / W. Kohler. - Berlin : Braunschweig : Friedr. Vieweg und Sohn,1920. - 263 s.

5. Lewin K. Defining the 'Field at a Given Time' / K. Lewin // Psychological Review. -1943. - Vol. 50 (3). - P. 292-310.

6. Heider F. Attitudes and Cognitive Organizations / F. Heider // Journal of Psychology. - 1946. - Vol. 21. - P. 107-112.

7. Zanjonc R. B. The Selected Works / R. B. Zajonc. -New York :Wiley, 2003. $-432 \mathrm{p}$.

8. Аронсон Э. Теория диссонанса: прогресс и проблемы / Э. Аронсон // Современная зарубежная социальная психология. -М. : Издательство МГУ, 1984. -С. 111-126. мин, стилю самоактуалізації і стилю розуміння. Неможливість реалізувати свій стиль розуміння зазвичай не усвідомлюється суб'єктом, а механізми неусвідомлюваної психічної активності, на думку Ф. Б. Березіна, відіграють важливу роль у виникненні психологічного дискомфорту при навчанні, а отже, зниженні успішності у навчанні [12]. Отже, ситуація дисбалансу між “внутрішнім" i “зовнішнім", коли студент не може задовольнити свою когнітивну потребу, може бути причиною зниження навчальної мотивації, а відтак - неуспішності у навчанні.

Висновки. Таким чином, когнітивний дисонанс розуміється як будь-яка невідповідність між когніціями, тобто знаннями, думками або переконаннями. Виникнення дисонансу як дискомфортного психологічного стану змушує людину здійснити спробу нейтралізувати його і досягнути консонансу - відповідності знань, емоцій, думок, у першу чергу, у процесі пізнавальної активності. Разом з тим, при наявності когнітивного дисонансу людина, як правило, активно уникає ситуацій та інформації, які можуть призвести до зростання подібного дискомфорту. Раніше проблеми у сфері когнітивного дисонансу оцінювалися і розглядалися в основному як суто психологічні, але дедалі ширше залучення психологічного знання у педагогічну теорію і практику перенесло проблему когнітивного дисонансу в площину педагогіки. Ресурсні можливості вивчення цього питання у контексті педагогічної науки полягають у розробці алгоритму уникнення когнітивного дисонансу в процесі навчальної діяльності.

9. Кононова М. М. Когнітивний дисонанс як детермінанта дезадаптації суб'єкта / М. М. Кононова // Актуальні проблеми психології: [зб. наук. праць Інституту психології ім. Г. С. Костюка АПН України].-К. : Логос, 2009. - Т. ХІ, ч. 2. С. 204-213.

10. Рейхет В. П. Способы снижения когнитивного диссонанса при обучении научной письменной речи на английском языке студентов искусствоведческих специальностей / В. П. Рейхет // Известия Российского государственного педагогического университета имени А. И. Герцена. 2008. - № 88. - С. 104-110.

11. Бэндлер Р. Семейная терапия и НЛП / Р. Бэндлер, Дж. Гриндер, В. Сатир. - М. : Институт общегуманитарных исследований, 1999. - 160 с.

12. Березин Ф. Б. Психическая и психофизиологическая адаптация человека / Ф. Б. Березин. - Л. : Наука, 1988. C. 13-21.

Отримано 16.01.15 